\title{
Production of Fine Count Yarns from Some Extra-long Egyptian Cottons on Different Spinning Systems
}

\author{
Eman Yehia Abd-Elkawe and Eman Rashwan El-Sayed
}

\section{ABSTRACT}

\begin{abstract}
The current research was carried out to produce fine count yarns from extra-long Egyptian cotton varieties using compact and ring spinning systems.in addition, to compare between compact yarns and ring yarns in terms of their physical and mechanical properties. Three commercial extralong staple Egyptian cottons Giza92, Giza93 and Giza 96 were used to produce four linear densities of $80,100,120$ and 140 at 3.6 twist multiplier. Results obtained showed that Giza 92 was surpassed significantly other extra -long staple varieties. It recorded the highest mean values of yarn strength and yarn evenness While, the same variety recorded the lowest mean values of yarn hairiness and imperfections. Compact yarns were much better than yarns spun on the ring spinning in yarn strength, yarn elongation, evenness, yarn imperfections and yarn hairiness. Yarn count 80; gave higher single yarn strength $(20.89 \mathrm{cN} /$ tex $)$, yarn elongation $(5.03 \%)$ and yarn evenness (17.49\%) and lower yarn hairiness (2.04) and imperfections than yarn count 140s. Single yarn strength, yarn elongation and yarn evenness were decreased with increasing yarn count. While the number of neps, hairiness, the number of thin and thick places were increased with increasing yarn count. Concerning, the effect of interaction between cotton varieties $\times$ yarn counts $\times$ spinning systems on yarn quality properties. Yarn count 80s recorded the highest mean values of yarn strength $(\mathbf{2 3 . 1 4}, 21.1$ and 20.2 cN/tex) and yarn evenness (17.72, 16.53 and $16.79 \%$ ) for varieties Giza92, Giza93 and Giza96, respectively for compact spinning system. Yarn strength at count $80,100,120$ and 140 correlated negatively and highly significant with micronaire value and maturity ratio.
\end{abstract}

Keywords: Fine count, Ring and compact spinning, Combed yarns, Yarn quality properties.

\section{INTRODUCTION}

Cotton fiber properties and spinning variables such as yarn count and spinning system are well known to play an important role in the efficiency and performance of spinning process besides the yarn quality [1]. Fibre quality is extremely important to the producer as it will largely determine the spinning efficiency of converting the fiber into yarn and the yarn to fabric. Spinning efficiency is affected by fiber fineness, maturity, trash, uniformity, and fiber to fiber adhesion, length, and fiber strength [2]. Spinning is one of the most cost processes in textile industry though, cotton breeders, technologists and spinners are primarily interested in translating the qualities of raw cotton into the qualities of yarn. Every spinning system produces yarn over a certain count range, and the limit of this range varies from system to system.

Ring spinning technology is the most widely accepted yarn production method. It is capable of spinning nearly all sorts of natural and synthetic fiber types within a very wide count range. In conventional ring system not all fibers that are placed at the external edges of the triangle can be spun into the yarn structure and can leave the drafting equipment without having been spun into the yarn [3]. Although, ring spinning machine is vastly used, it has some limitations such as unevenness and more hairiness that bounds the spinners to choose alternative spinning systems. Rotor was selected to produce more even yarn and compact spinning gives both even and less hairy yarn [4].

Compact spinning is one of the most important improvements in traditional ring spinning, which is implemented by adding fiber condensing device on a ring spinning frame to condense the fiber bundle and decrease or even eliminate spinning triangles, with the spun yarn structure and quality having a qualitative development since the fiber tension distributions in the spinning triangles are more uniform [5].The compact spinning process produces a new yarn structure which permits the reduction of the number of fibers in the cross section, or to spin a finer yarn count. Reducing the possibilities of the number of fibers in the cross section allows for the use of lower priced tops with coarser fibers. Reference [6] concluded that the compact yarns have the following advantages when compared to the conventional ring yarns: significantly reduced hairiness, smooth Surface, high gloss, improved tenacity, elongation percentage, evenness, and imperfections. Reference [7] stated that Combing process plays important role it is improve the quality of raw material by removing short fiber, trash 
particles and neps present in it. Combed yarn has appearance, strength, evenness, and luster better than carded yarn.

Our objectives in this investigation were to produce fine count yarns from extra-long Egyptian cotton varieties using compact and ring spinning systems. Moreover, compare between compact yarns spun and the conventional ring-spun yarns in terms of their physical and mechanical properties.

\section{MATERIALS AND METHODS}

This study was conducted in El Shorbagy Company for Spinning and Waving. Three commercial Egyptian cotton varieties i.e., Giza 92, G93 and Giza 96 as extra-long staple cotton varieties were used to produce several ring and compact yarns. Ring and compact yarns were produced with four linear densities $80 \mathrm{~s}, 100 \mathrm{~s}, 120 \mathrm{~s}$ and 140s at 3.8 twist multiplier. The combed yarns were manufactured from the same varieties, eliminating $18 \%$ of noils during combing.

Cotton fiber and yarn testing were carried out in the laboratories of Cotton Technology Research Division, Cotton Research Institute, Agricultural Research Centre, Egypt. About $10 \mathrm{Kg}$ of lint was taken in order to perform both fiber and yarn tests. Fiber properties were measured by using High Volume Instrument (HVI) according to ASTM [8].

Yarn strength (cN/tex) and yarn elongation (\%) were measured by Statimat Me according to ASTM [9] with testing speed of $5000 \mathrm{~mm} / \mathrm{min}$ and test length of $50 \mathrm{~cm}$ used for the testing of tensile properties. Average of 120 breaks per sample. Yarn evenness (C.V. \%) and number of imperfections were measured according to ASTM [9] by the Uster Tester 3 with $400 \mathrm{~mm} / \mathrm{min}$ testing speed and I min testing time at $-50 \%,+50 \%$ and $+200 \%$ sensitivity levels for thin places, thick places and neps respectively. All the samples were tested under laboratory conditions of $65 \pm 2 \%$ relative humidity and $21 \pm 1{ }^{\circ} \mathrm{C}$ temperature.

The experimental design of this study was conducted as a completely randomized design with three replications and analyzed as factorial experiment according to the method described by [10]. The value of the significance level selected for all statistical tests in the study was 0.05 according to [11]. All statistical procedures were conducted using the SPSS 20 statistical software package.

Fiber properties of the studied commercial extra-long staple cottons, Giza 92, Giza93 and Giza 96 are presented in Table I. Giza96 had the lowest fiber strength among the extra-long staple cottons. Also, Giza96 showed the highest maturity ratio and yellowness. While, Giza 92 gave higher upper half mean, uniformity ratio and fiber strength than other extra -long staple varieties.

TABLE I: FIBER QUALITY PROPERTIES MEASURED BY HVI

\begin{tabular}{cccc}
\hline \multicolumn{4}{c}{ Cotton varieties } \\
\hline Fiber properties & Giza 92 & Giza 93 & Giza 96 \\
Upper Half Mean "mm" & 35.72 & 33.54 & 33.56 \\
Uniformity index \% & 86.07 & 84.87 & 85.37 \\
Short Fiber Index \% & 5.23 & 5.43 & 5.43 \\
Strength "g/tex" & 45.53 & 45.03 & 43.50 \\
Elongation \% & 4.23 & 4.67 & 4.50 \\
Micronaire value & 2.99 & 3.60 & 3.86 \\
Maturity \% & 0.88 & 0.91 & 0.92 \\
Reflectance (Rd \%) & 70.23 & 67.13 & 75.33 \\
Yellowness (+b) & 9.53 & 11.70 & 9.57 \\
\hline
\end{tabular}

\section{RESULTS}

Data presented in Table II showed the main effects of cotton varieties, spinning systems and yarn counts on yarn quality properties. Spinning systems and yarn counts had significant effects on all yarn quality properties. Also, cotton varieties had significant effect on all yarn properties except yarn elongation $\%$ and number of neps $(+200)$.

\section{A. Mechanical Yarn Properties (Yarn Strength and Yarn Elongation)}

As shown in Table II, cotton varieties had significant effect on all yarn properties except yarn elongation \%. Giza 92 was surpassed significantly other extra -long staple varieties. It recorded the highest mean value of yarn strength (21.44cN/tex) followed by Giza93 (18.91cN/tex). While Giza 96 gave the lowest mean value of yarn strength $(17.93 \mathrm{cN} /$ tex $)$. The spinning systems had significant effects on yarn strength and yarn elongation. Generally, compact yarn strength $(20.20 \mathrm{cN} /$ tex $)$ and yarn elongation $(4.42 \%)$ were higher than conventional yarn strength $(18.65 \mathrm{cN} / \mathrm{tex})$ and elongation $(4.13 \%)$ due to all fibers contribute to yarn formation during spinning in compact system.

As shown in Table II, all yarn properties were significantly affected by yarn counts. Yarn count 80 s gave the highest mean values of single yarn strength $(20.89 \mathrm{cN} /$ tex $)$ and elongation ratio $(5.03 \%)$. On the other hand, the lowest mean values of strength $(18.01 \mathrm{cN} /$ tex $)$ and elongation $(3.67 \%)$ were recorded by yarn count 140 s. It noticed that single yarn strength (cN/tex) and yarn elongation $(\%)$ were decreased significantly by increasing yarn count. Generally, it could be concluded that single yarn strength correspondingly increased by increasing numbers of fibers in yarn crosssection. Furthermore, yarn strength increased with increasing the number of longer fibers in yarn due to the greater number of points of contact and cohesion between them, and consequently increased yarn strength [12].

\section{B. Physical Yarn Properties (Yarn Evenness Imperfections and Yarn Hairiness)}

Data presented in Table II showed that cotton varieties had significant effect on yarn evenness, (CV \%), Neps, thin ($50 \%)$ and thick places $(+50 \%)$ and yarn hairiness. Giza93 was recorded the highest mean values of thin places (209) and yarn hairiness (2.38). On the other side, the highest mean values of yarn evenness (19.05), Neps (177), thin (82) and thick places (214) and yarn hairiness (1.95) recorded by Giza 92. The experimental results of ring (conventional) and compact are given in Table II. According to statistical analysis, all yarn properties were significantly affected by spinning systems. Compact spinning system recorded the highest mean value of yarn evenness (17.97) and the lowest mean values of thin places (61), thick places (156), neps (136) and yarn hairiness (1.97).

These results are in agreement with those obtained by [13] and [14] who reported that compact spun yarns have higher strength, higher elongation ratio, higher yarn evenness, lower hairiness, and lower imperfections compared to conventional yarns. As shown in Table II, all yarn properties were significantly affected by yarn counts. Yarn count 80 , s gave the highest mean value of yarn evenness (17.49) and the lowest mean values of thin places (28), thick places (158), 
neps (122) and yarn hairiness (2.04). While, yarn count 140s gave the lowest mean value of evenness (21.72) and the highest mean values of thin places (328), thick places (384), neps (309) and yarn hairiness (2.42). It noticed that yarn evenness was increased with increasing yarn count. While the number of neps, yarn hairiness, the number of thin and thick places were increased with increasing yarn count.

These results are in agreement with those obtained by [15], [16], [17] and [18] who found that yarn linear density had significant effect on all yarn properties. Yarn unevenness, the number of thin places, thick places, neps and yarn hairiness were increased with increasing yarn linear density. In contrary, yarn strength and yarn elongation were decreased with increasing linear density that may be due to the lower number of fibers in cross section of fine yarns.

\section{The Interaction between Cotton Varieties and Spinning System (VxS)}

According to the data given in Table III, it could be noticed that the first order interaction between Egyptian cotton varieties and spinning systems $(\mathrm{V} \times \mathrm{S})$ was significantly affect all yarn quality properties except for yarn elongation $\%$ and number of neps $/ 400 \mathrm{~m}$. Concerning the yarn strength (cN/tex), the highest mean values of single yarn strength recorded by Giza92 for each ring and compact spinning Systems 20.47 and $22.42 \mathrm{cN} /$ tex, respectively. Whereas the lowest mean values recorded by Giza 96 for each ring and compact spinning systems 17.26 and $18.59 \mathrm{cN} /$ tex, respectively. Giza 92 for each ring and compact spinning systems recorded the highest mean values of yarn evenness (19.88 and $18.22 \%)$ and the lowest mean values of thin places (117 and $47400 / \mathrm{m}$ ), thick places (266 and 161 $400 / \mathrm{m}$ ) and hairiness (2.26 and 1.64). Generally, it could be reported that yarn unevenness and yarn hairiness of compact yarns are significantly lower when compared with yarn evenness and yarn hairiness with conventional ring yarns.

\section{The Interaction between Cotton Varieties and Yarn Count (VX C)}

Data presented in Table IV showed the first interaction between extra-long cotton varieties and yarn counts $(\mathrm{V} \times \mathrm{C})$ for yarn quality properties. The highest mean value of yarn strength $22.44 \mathrm{cN} /$ tex was recorded by Giza 92 using yarn count 80 s. On the other hand, Giza96 using yarn count 140 s recorded the lowest mean value of yarn strength 16.57 cN/tex. While Giza93 using yarn count 80 s recorded the highest mean value for yarn evenness $(16.93 \%)$ and the lowest mean value of thick places (141). These results were in agreement with the findings of [19], [20], [21], [22] and [23] who reported that the interaction between cotton varieties and yarn counts had significant effect on lea count strength product, yarn hairiness, C.V. \%, neps/100m, thin places/100 $\mathrm{m}$ and thick places/100 m).

\section{E. The Interaction between Yarn Counts and Spinning Systems $(C \times S)$}

As shown in Table $\mathrm{V}$, the interaction between yarn counts and spinning systems $(\mathrm{C} \times \mathrm{S})$ was significantly affect all yarn quality properties except for yarn elongation $\%$ and number of neps $/ 400 \mathrm{~m}$. Yarn count 80 s recorded the highest mean values of yarn strength (20.30 and $21.48 \mathrm{cN} / \mathrm{tex})$, yarn elongation (5.05 and 5.02\%) and yarn evenness (17.96 and
$17.01 \%$ ) for each ring and compact spinning systems, respectively. While the same count recorded the lowest mean values of thin places $(14 / 400 \mathrm{~m})$ and yarn hairiness (1.77) for compact spinning system. Yarn count 140s recorded the lowest mean values of yarn strength $(17.30 \mathrm{cN} / \mathrm{tex})$, yarn elongation $(3.45 \%)$ and yarn evenness $(23.94 \%)$ for ring spinning system. On the other side, the same count recorded the highest mean values of thin places $(514 / 400 \mathrm{~m})$, thick places $(570 / 400 \mathrm{~m})$ and yarn hairiness (32.63) for ring spinning system. [1] reported that fiber properties and spinning variables such as yarn count and spinning system are well known to play an important role in the efficiency and performance of spinning process besides the yarn quality. The Interaction among Cotton Varieties, Spinning Systems and Yarn Counts ( $V x S x C$ ).

Regarding data in Table VI and Fig. 1, 2 and 3 showed that the second order interaction among cotton varieties, spinning systems and yarn counts $(\mathrm{V} \times \mathrm{C} \times \mathrm{S})$ was significantly affect all yarn quality properties except for yarn elongation $\%$ and number of neps $/ 400 \mathrm{~m}$. Yarn count 80 s recorded the highest mean values of yarn strength $(23.14,21.1$ and $20.2 \mathrm{cN} /$ tex $)$ and yarn evenness $(17.72,16.53$ and $16.79 \%)$ for varieties Giza92, Giza93 and Giza96, respectively for compact spinning system. While, the same count recorded the lowest mean values of thin places $(18,15$ and 8$)$, thick places (157, 104 and 152) and yarn hairiness (1.51,1.79 and 2.01) for varieties Giza92, Giza93 and Giza96, respectively for compact spinning system. On the other hand, yarn count 140s recorded the lowest mean values of yarn strength (19.37, 16.55 and $15.97 \mathrm{cN} /$ tex $)$ and yarn evenness $(21.47,25.92$ and 24.44\%) for varieties Giza92, Giza93 and Giza96, respectively for ring spinning system. In contrary, the same count recorded the highest mean values of thin places (249,772 and 519), thick places $(407,734$ and 568) and yarn hairiness $(2.41,2.82$ and 2.66).

Generally, compact spinning system gave better yarn quality properties compare to ring spinning system for all yarn counts. Compact spinning system is more appropriate for long staple varieties, coarse and medium counts than for the extra-long staple varieties and finer counts [24].

\section{F. Relationship between Yarn Properties and Fiber Properties}

The correlation between fiber and yarn properties under different yarn counts shown in Table VII. The results indicated that yarn strength at count 80s, 100s, 120s and 140s correlated negatively and highly significant with micronaire value and maturity ratio. However, it had positive highly significant correlation with upper half mean length at all yarn counts. Also, yarn strength at 80 s, 100s and 140s yarn count correlated positively and highly significant with fiber strength. Yarn unevenness (CV\%) showed Negative significant correlations with upper half mean length and fiber strength at all yarn counts. It noticed that yarn unevenness decreased with increasing maturity ratio (\%) and fiber strength (g/tex). Yarn hairiness at 80s, 100s, 120s and 140s yarn counts correlated positively and highly significant with micronaire value and maturity ratio. While, it had negative significant correlation with upper half mean length at all yarn counts. 
European Journal of Agriculture and Food Sciences www.ejfood.org

TABLE II: MAIN EFFECTS OF COTTON VARIETIES, SPINNING SYSTEMS AND YARN COUNTS ON YARN QUALITY PROPERTIES

\begin{tabular}{|c|c|c|c|c|c|c|c|}
\hline \multirow{2}{*}{$\begin{array}{l}\text { Treatments } \\
\text { Varieties }\end{array}$} & \multicolumn{7}{|c|}{ Yarn properties } \\
\hline & $\begin{array}{l}\text { Strength } \\
\text { (cN/tex) }\end{array}$ & $\begin{array}{c}\text { Elongation } \\
\%\end{array}$ & $\mathrm{CV} \%$ & $\begin{array}{r}\text { Thin } \\
-50 \% \\
\end{array}$ & $\begin{array}{l}\text { Thick } \\
+50 \%\end{array}$ & Neps $200 \%$ & Hairiness \\
\hline Giza92 & 21.44 & 4.33 & 19.05 & 82 & 214 & 177 & 1.95 \\
\hline Giza93 & 18.91 & 4.2 & 19.7 & 209 & 294 & 227 & 2.38 \\
\hline Giza96 & 17.93 & 4.29 & 19.76 & 172 & 282 & 228 & 2.34 \\
\hline LSD & 0.591 & Ns & 0.546 & 47.3 & 33.94 & Ns & 0.122 \\
\hline Spinning & $\begin{array}{l}\text { Strength } \\
(\mathrm{cN} / \text { tex })\end{array}$ & Elongation \% & $\mathrm{CV} \%$ & Thin $-50 \%$ & Thick $+50 \%$ & Neps $200 \%$ & Hairiness \\
\hline Ring & 18.65 & 4.13 & 21.04 & 248 & 370 & 285 & 2.48 \\
\hline Compact & 20.20 & 4.42 & 17.97 & 61 & 156 & 136 & 1.97 \\
\hline LSD & $* *$ & $* *$ & $* *$ & $* *$ & $* *$ & $* *$ & $* *$ \\
\hline Count & $\begin{array}{l}\text { Strength } \\
\text { (cN/tex) }\end{array}$ & Elongation \% & $\begin{array}{l}\mathrm{CV} \\
\%\end{array}$ & Thin $-50 \%$ & Thick $+50 \%$ & $\begin{array}{l}\text { Neps } \\
200 \%\end{array}$ & Hairiness \\
\hline 80 & 20.89 & 5.03 & 17.49 & 28 & 158 & 122 & 2.04 \\
\hline 100 & 19.77 & 4.44 & 18.91 & 89 & 216 & 199 & 2.16 \\
\hline 120 & 19.03 & 3.95 & 19.92 & 172 & 296 & 214 & 2.28 \\
\hline 140 & 18.01 & 3.67 & 21.72 & 328 & 384 & 309 & 2.42 \\
\hline LSD & 0.683 & 0.386 & 0.631 & 54.61 & 39.19 & 86.68 & 0.141 \\
\hline
\end{tabular}

TABLE III: THE INTERACTION BETWEEN EXTRA-LONG COTTON VARIETIES AND SPINNING SYSTEMS (V × S) FOR YARN QUALITY PROPERTIES

\begin{tabular}{|c|c|c|c|c|c|c|c|c|}
\hline Varieties & Spinning & $\begin{array}{l}\text { Strength } \\
\text { (cN/tex) }\end{array}$ & $\begin{array}{c}\text { Elongation } \\
\%\end{array}$ & $\begin{array}{c}\mathrm{CV} \\
\%\end{array}$ & $\begin{array}{l}\text { Thin } \\
-50 \%\end{array}$ & $\begin{array}{l}\text { Thick } \\
+50\end{array}$ & $\begin{array}{l}\text { Neps } \\
+200 \\
\end{array}$ & Hairiness \\
\hline \multirow{2}{*}{ Giza92 } & Ring & 20.47 & 4.30 & 19.88 & 117 & 266 & 251 & 2.26 \\
\hline & compact & 22.42 & 4.36 & 18.22 & 47 & 161 & 103 & 1.64 \\
\hline \multirow{2}{*}{ Giza93 } & Ring & 18.22 & 4.03 & 21.72 & 358 & 456 & 302 & 2.73 \\
\hline & compact & 19.59 & 4.38 & 17.69 & 61 & 132 & 152 & 2.02 \\
\hline \multirow{3}{*}{ Giza96 } & Ring & 17.26 & 4.06 & 21.52 & 269 & 389 & 302 & 2.45 \\
\hline & compact & 18.59 & 4.53 & 18.01 & 74 & 175 & 154 & 2.23 \\
\hline & LSD & 0.84 & Ns & 0.77 & 66.89 & 48 & Ns & 0.17 \\
\hline
\end{tabular}

TABLE IV: THE INTERACTION BETWEEN COTTON VARIETIES AND YARN COUNTS $(\mathrm{V} \times \mathrm{C})$ FOR YARN QUALITY PROPERTIES

\begin{tabular}{|c|c|c|c|c|c|c|c|c|}
\hline Varieties & Count & $\begin{array}{l}\text { Strength } \\
\text { (cN/tex) }\end{array}$ & Elongation \% & $\begin{array}{l}\mathrm{CV} \\
\%\end{array}$ & $\begin{array}{l}\text { Thin } \\
-50 \%\end{array}$ & $\begin{array}{l}\text { Thick } \\
+50\end{array}$ & $\begin{array}{l}\text { Neps } \\
+200\end{array}$ & Hairiness \\
\hline \multirow{4}{*}{ Giza92 } & 80 & 22.44 & 5.36 & 18.04 & 38 & 170 & 96 & 1.77 \\
\hline & 100 & 21.94 & 4.26 & 18.75 & 36 & 179 & 140 & 1.92 \\
\hline & 120 & 21.17 & 4.08 & 18.99 & 73 & 206 & 185 & 1.98 \\
\hline & 140 & 20.22 & 3.61 & 20.43 & 180 & 300 & 288 & 2.13 \\
\hline \multirow{4}{*}{ Giza93 } & 80 & 20.59 & 5.02 & 16.93 & 24 & 141 & 84 & 2.19 \\
\hline & 100 & 19.37 & 4.60 & 18.98 & 125 & 247 & 191 & 2.33 \\
\hline & 120 & 18.42 & 3.66 & 20.29 & 233 & 336 & 277 & 2.45 \\
\hline & 140 & 17.24 & 3.53 & 22.60 & 455 & 451 & 356 & 2.54 \\
\hline \multirow{4}{*}{ Giza96 } & 80 & 19.64 & 4.72 & 17.49 & 22 & 163 & 185 & 2.15 \\
\hline & 100 & 18.01 & 4.46 & 18.99 & 106 & 221 & 265 & 2.22 \\
\hline & 120 & 17.49 & 4.13 & 20.47 & 210 & 344 & 179 & 2.40 \\
\hline & 140 & 16.57 & 3.86 & 22.11 & 348 & 400 & 281 & 2.60 \\
\hline LSD & & 1.183 & Ns & 1.092 & 94.59 & 67.88 & Ns & Ns \\
\hline
\end{tabular}

TABLE V: THE INTERACTION BETWEEN YARN COUNTS AND SPINNING SYSTEMS $(\mathrm{C} \times \mathrm{S})$ FOR YARN QUALITY PROPERTIES

\begin{tabular}{|c|c|c|c|c|c|c|c|c|}
\hline Count & Spinning & $\begin{array}{l}\text { Strength } \\
\text { (cN/tex) }\end{array}$ & Elongation \% & $\begin{array}{c}\mathrm{CV} \\
\%\end{array}$ & $\begin{array}{c}\text { Thin } \\
-50 \% \\
\end{array}$ & $\begin{array}{l}\text { Thick } \\
+50 \\
\end{array}$ & Neps +200 & Hairiness \\
\hline \multirow{2}{*}{80} & Ring & 20.30 & 5.05 & 17.96 & 42 & 178 & 165 & 2.30 \\
\hline & compact & 21.48 & 5.02 & 17.01 & 14 & 138 & 78 & 1.77 \\
\hline \multirow{2}{*}{100} & Ring & 18.84 & 4.23 & 20.31 & 133 & 297 & 282 & 2.46 \\
\hline & compact & 20.07 & 4.65 & 17.50 & 45 & 135 & 115 & 1.86 \\
\hline \multirow{2}{*}{120} & Ring & 18.17 & 3.78 & 21.95 & 302 & 437 & 282 & 2.53 \\
\hline & compact & 19.89 & 4.13 & 17.88 & 42 & 154 & 146 & 2.02 \\
\hline \multirow{2}{*}{140} & Ring & 17.30 & 3.45 & 23.94 & 514 & 570 & 411 & 2.63 \\
\hline & compact & 18.73 & 3.88 & 19.49 & 142 & 198 & 206 & 2.21 \\
\hline LSD & & 0.97 & Ns & 0.89 & 77.23 & 55.43 & Ns & 0.20 \\
\hline
\end{tabular}


European Journal of Agriculture and Food Sciences www.ejfood.org

TABLE VI: THE INTERACTION BETWEEN EXTRA-LONG COTTON VARIETIES, SPINNING SYSTEMS AND YARN COUNTS $($ V $\times$ S $\times$ C) FOR YARN QUALITY

\begin{tabular}{|c|c|c|c|c|c|c|c|c|c|}
\hline \multicolumn{10}{|c|}{ PROPERTIES } \\
\hline Varieties & Spinning & Count & $\begin{array}{l}\text { Strength } \\
\text { (cN/tex) }\end{array}$ & $\begin{array}{c}\text { Elongation } \\
\%\end{array}$ & $\begin{array}{c}\mathrm{CV} \\
\%\end{array}$ & $\begin{array}{l}\text { Thin } \\
-50 \%\end{array}$ & $\begin{array}{l}\text { Thick } \\
+50\end{array}$ & $\begin{array}{l}\text { Neps } \\
+200\end{array}$ & Hairiness \\
\hline \multirow{2}{*}{ Giza92 } & Ring & \multirow{6}{*}{80} & 21.74 & 5.35 & 18.36 & 58 & 183 & 124 & 2.03 \\
\hline & compact & & 23.14 & 5.38 & 17.72 & 18 & 157 & 68 & 1.51 \\
\hline \multirow{2}{*}{ Giza93 } & Ring & & 20.08 & 5.09 & 17.33 & 32 & 177 & 92 & 2.6 \\
\hline & compact & & 21.1 & 4.95 & 16.53 & 15 & 104 & 75 & 1.79 \\
\hline \multirow{2}{*}{ Giza96 } & Ring & & 19.08 & 4.7 & 18.19 & 37 & 174 & 278 & 2.29 \\
\hline & compact & & 20.2 & 4.73 & 16.79 & 8 & 152 & 92 & 2.01 \\
\hline \multirow{2}{*}{ Giza92 } & Ring & \multirow{6}{*}{100} & 20.85 & 4.14 & 19.66 & 42 & 203 & 214 & 2.26 \\
\hline & compact & & 23.02 & 4.39 & 17.84 & 30 & 155 & 66 & 1.58 \\
\hline \multirow{2}{*}{ Giza93 } & Ring & & 18.54 & 4.54 & 20.68 & 196 & 375 & 244 & 2.73 \\
\hline & compact & & 20.19 & 4.67 & 17.28 & 54 & 119 & 139 & 1.93 \\
\hline \multirow{2}{*}{ Giza96 } & Ring & & 17.11 & 4.02 & 20.59 & 162 & 312 & 389 & 2.39 \\
\hline & compact & & 18.9 & 4.9 & 17.39 & 50 & 131 & 141 & 2.05 \\
\hline \multirow{2}{*}{ Giza92 } & Ring & & 19.93 & 4.23 & 20.05 & 117 & 273 & 270 & 2.34 \\
\hline & compact & & 22.42 & 3.94 & 17.93 & 29 & 140 & 100 & 1.62 \\
\hline \multirow{2}{*}{ Giza93 } & Ring & & 17.7 & 3.31 & 22.93 & 431 & 536 & 368 & 2.79 \\
\hline & compact & 120 & 19.15 & 4.01 & 17.65 & 36 & 136 & 186 & 2.1 \\
\hline \multirow{2}{*}{ Giza96 } & Ring & & 16.88 & 3.81 & 22.88 & 359 & 503 & 206 & 2.45 \\
\hline & compact & & 18.11 & 4.44 & 18.06 & 61 & 186 & 152 & 2.35 \\
\hline \multirow{2}{*}{ Giza92 } & Ring & & 19.37 & 3.49 & 21.47 & 249 & 407 & 397 & 2.41 \\
\hline & compact & & 21.08 & 3.72 & 19.4 & 110 & 193 & 180 & 1.85 \\
\hline \multirow{2}{*}{ Giza93 } & Ring & & 16.55 & 3.16 & 25.92 & 772 & 734 & 504 & 2.82 \\
\hline & compact & 140 & 17.93 & 3.9 & 19.28 & 138 & 168 & 208 & 2.26 \\
\hline \multirow{2}{*}{ Giza96 } & Ring & & 15.97 & 3.7 & 24.44 & 519 & 568 & 333 & 2.66 \\
\hline & compact & & 17.17 & 4.02 & 19.78 & 176 & 232 & 229 & 2.54 \\
\hline LSD & & & 1.673 & Ns & 1.549 & 133.77 & 96 & Ns & 0.345 \\
\hline
\end{tabular}

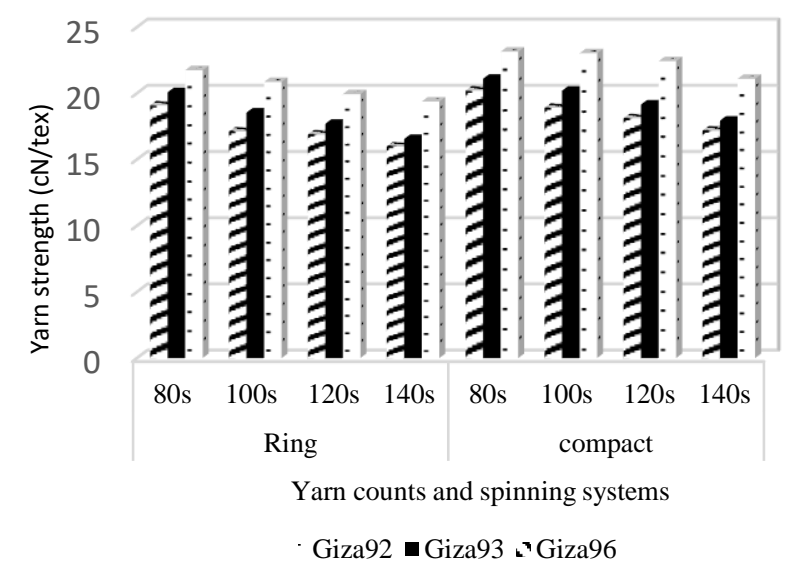

Fig. 1. Single yarn strength as affected by the interaction between cotton varieties, spinning systems and yarn counts.

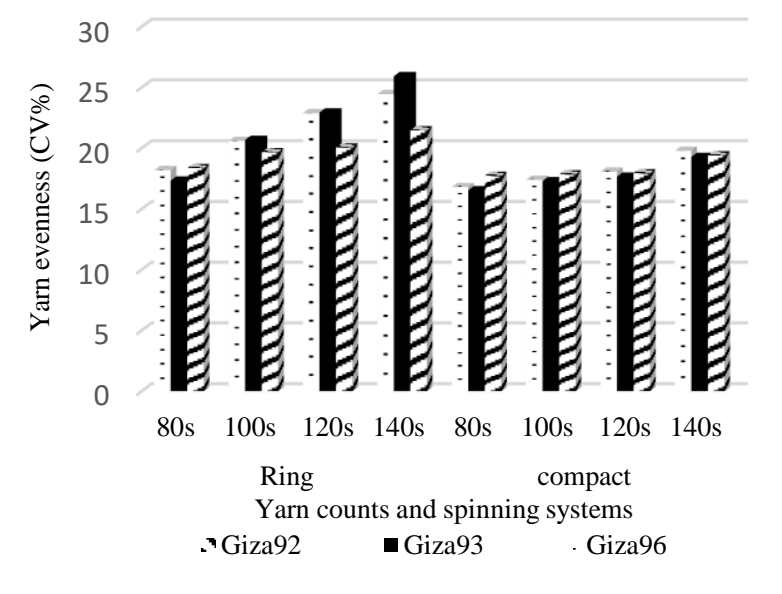

Fig. 2. Yarn evenness (CV \%) as affected by the interaction between cotton varieties, spinning systems and yarn counts.

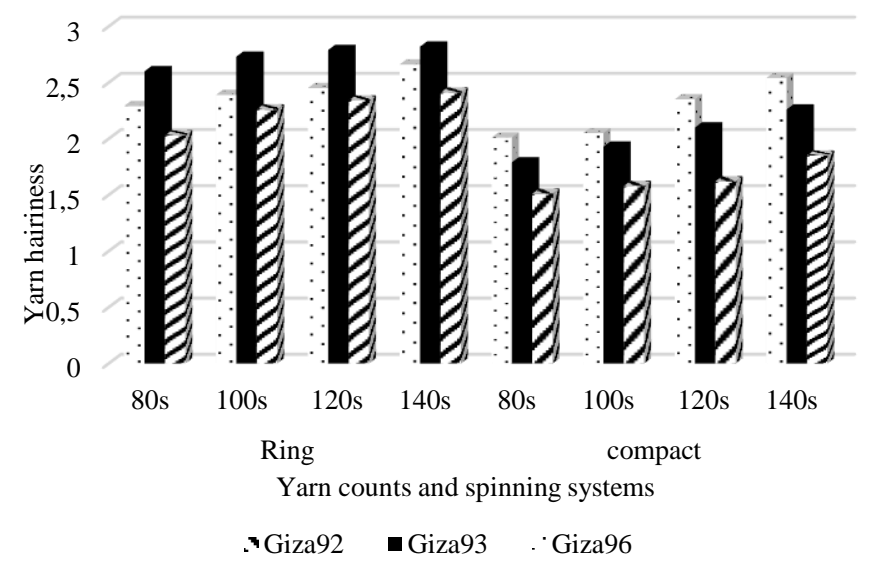

Fig. 3. Yarn hairiness as affected by the interaction between cotton varieties, spinning systems and yarn counts. 
TABLE VII: CORRELATION COEFFICIENT BETWEEN YARN PROPERTIES AND FIBER PROPERTIES AT 80s, 100s, 120s AND 140s YARN COUNTS USING RING AND COMPACT SPINNING SYSTEMS

\begin{tabular}{|c|c|c|c|c|c|c|}
\hline \multirow{2}{*}{$\begin{array}{c}\text { Yarn } \\
\text { properties }\end{array}$} & \multirow[b]{2}{*}{ Count } & \multirow{2}{*}{$\begin{array}{l}\text { Spinning } \\
\text { system }\end{array}$} & \multicolumn{4}{|c|}{ Fiber properties } \\
\hline & & & Micronaire & Maturity $\%$ & UHM (mm) & $\begin{array}{c}\text { Fiber strength } \\
(\mathrm{g} / \mathrm{tex})\end{array}$ \\
\hline \multirow{8}{*}{$\begin{array}{l}\text { Strength } \\
(\mathrm{cN} / \text { tex })\end{array}$} & \multirow{2}{*}{80} & Ring & $-0.713^{*}$ & $-0.662 *$ & $0.609 *$ & $0.666^{*}$ \\
\hline & & Compact & $-0.876^{* *}$ & $-0.875^{* *}$ & $0.899 * *$ & 0.599 \\
\hline & \multirow{2}{*}{100} & Ring & $-0.918 * *$ & $-0.934 * *$ & $0.848^{* *}$ & 0.628 \\
\hline & & Compact & $-0.850 * *$ & $-0.839 * *$ & $0.824 * *$ & $0.700^{*}$ \\
\hline & \multirow{2}{*}{120} & Ring & $-0.918 * *$ & $-0.934 * *$ & $0.848 * *$ & 0.628 \\
\hline & & Compact & -0.661 & $-0.726^{*}$ & 0.544 & 0.325 \\
\hline & \multirow{2}{*}{140} & Ring & $-0.850 * *$ & $-0.839 * *$ & $0.824 * *$ & $0.700^{*}$ \\
\hline & & Compact & $-0.942 * *$ & $-0.917 * *$ & $0.897 * *$ & 0.659 \\
\hline \multirow{8}{*}{$\mathrm{CV} \%$} & \multirow{2}{*}{80} & Ring & 0.463 & 0.29 & -0.329 & $-0.787 * *$ \\
\hline & & Compact & 0.639 & 0.626 & -0.59 & -0.41 \\
\hline & \multirow{2}{*}{100} & Ring & 0.354 & 0.227 & -0.238 & $-0.682 *$ \\
\hline & & Compact & $0.776^{*}$ & $0.808 * *$ & $-0.673 *$ & -0.386 \\
\hline & \multirow{2}{*}{120} & Ring & 0.354 & 0.227 & -0.238 & $-0.682 *$ \\
\hline & & Compact & 0.617 & 0.623 & -0.511 & -0.312 \\
\hline & \multirow{2}{*}{140} & Ring & $0.776^{*}$ & $0.808 * *$ & $-0.673^{*}$ & -0.386 \\
\hline & & Compact & 0.204 & 0.212 & -0.388 & 0.039 \\
\hline \multirow{8}{*}{ Hairiness } & \multirow{2}{*}{80} & Ring & 0.546 & $0.613 *$ & $-0.649 *$ & -0.155 \\
\hline & & Com & 0.58 & 0.631 & -0.505 & -0.265 \\
\hline & \multirow{2}{*}{100} & Ring & 0.319 & 0.4 & -0.436 & -0.141 \\
\hline & & Com & $0.772 *$ & $0.790 *$ & $-0.737 *$ & -0.583 \\
\hline & \multirow{2}{*}{120} & Ring & 0.319 & 0.4 & -0.436 & -0.141 \\
\hline & & Com & $0.772 *$ & $0.751 *$ & $-0.723 *$ & -0.654 \\
\hline & \multirow{2}{*}{140} & Ring & $0.772 *$ & $0.790 *$ & $-0.737 *$ & -0.583 \\
\hline & & Com & $0.830^{* *}$ & $0.786^{*}$ & $-0.743 *$ & -0.601 \\
\hline
\end{tabular}

\section{CONCLUSIONS}

The main objective of this study to produce four fine yarn counts $80,100,120$ and 140 at the same twist multiplier 3.6 from three extra-long staple cotton varieties namely Giza92, Giza93 and Giza 96 using ring and compact spinning systems. Also, it made comparison between ring and compact yarns in yarn quality properties. Fiber properties were estimated by HVI, mechanical yarn properties (yarn strength and yarn elongation) were measured by Statimat Me and physical yarn properties (yarn evenness, yarn hairiness, thin places, thick places, and number of neps) were measured by Uster tester 3 . The experimental design was randomized complete design, with three replications. From the results of this study, it was clear that Giza92 was much better than all extra-long staple cotton varieties under study in mechanical and physical yarn quality properties. The yarn count 140 recorded the lower yarn strength, yarn elongation and the higher yarn unevenness, yarn hairiness and number of thin, thick and neps places $/ 400 \mathrm{~m}$ as compare with yarn count 80 . Ring yarns recorded the highest yarn hairiness and yarn imperfections and the lowest yarn strength and yarn elongation than compact yarns.

\section{ACKNOWLEDGEMENTS}

The authors wish to express his deepest gratitude and sincere appreciation to El Shorbagy Company for Spinning and Waving and spinning research department at Cotton Research Institute at ARC, Egypt for providing up to date laboratory apparatus.

\section{REFERENCES}

[1] M.N. El Banna, M.A.M. El- Sayed, M.A.A. Nassar and A.A.A. ElBanna, "Impact of ring and compact spinning systems on the quality of Egyptian cotton properties," 2nd Alexandria International of Cotton Conference, Alexandria Univ. Egypt, 10-11 April 2013.
[2] H.D. Kenndy, Selection and response of yield and fiber traits in upland cotton, M.S. Thesis. Texas A\&M Univ., USA. pp. 1-85. 2018.

[3] N. Ozdil, E. Ozdogan, A. Demirel and T. Oktem, "A comparative study of the cha racteristics of compact yarn based knitted fabrics," Fibers \& Textile in Eastern Europe, Vol. 13, no.2, pp. 39-43, 2005.

[4] Z.M.D. Islam, "Comparing quality parameters of yarn produced by ring, rotor, and compact spinning system," European scientific Journal, Vol. 15, no. 3, pp. 1857-7881, 2019.

[5] M. Nikolic, Z. Stjepanovic, F. Lesjak, and A. Stritof, "Compact spinning for improved quality of ring spun yarns," Fibers \& Textiles in Eastern Europe, Vol. 11, no. 4, pp. 30-35, 2003.

[6] M. R. Rashid, F. Ahmed, A.K. Azad, and A.N.M. Ullah, "Comparative study on cotton yarn quality made from compact and conventional ring frame," Journal of Innovation \& Development Strategy, Vol. 5, no. 3, pp. 61-66, 2011.

[7] S. Subramanian, and N. Gobi, "Effect of process parameters at comber on yarn and fabric properties," Indian Journal of Fiber \&Textile Research, Vol. 29, no. 2, pp. 196-199, 2004.

[8] ASTM, American Society for Testing and Materials. Standards of Textile Testing and Materials D 4605-86, USA. 1986.

[9] ASTM, American Society for Testing and Materials. Standards of Textile Testing and Materials, Philadelphia, Pa. D2256-91, D142591.USA.1991

[10] K. A. Gomez and A. A. Gomez, "Statistical procedures for agricultural research 2nd edition," John Willey \& Sons, New York. USA. pp.704, 1984.

[11] W. Snedecor and W.G. Cochran, "Statistical methods $7^{\text {th }}$ ed," Iowa State Univ., Press Ames, Iowa. 1980.

[12] M.H. El- Shakankery, A.E.I. Ibrahim, AEAE El-Banna, "Predicting strength properties for ring and compact Egyptian cotton spun yarns using artificial neural network," Journal of the Textile Association, pp. 346-352, 2014.

[13] S. E. D. Elayan, A. M. Abdalla, N. T. Ahmed, E. R. El-Sayed. "Comparison between ring and compact spun from long staple Egyptian cotton varieties," Journal of Agriculture. Science. Mansoura Univ., Vol. 33, no. 7 pp. 4761-4769, 2008.

[14] S. Altas and H. Kadoğlu, "Comparison of conventional ring, mechanical compact and pneumatic compact yarn spinning systems," Journal of Engineered Fibers and Fabrics, Vol. 7, no.1, pp. 87-100, 2012.

[15] H. Deussen, "Improved cotton fiber properties the textile industry's key to success in global competition," In Proc. Beltwide Cotton Conference, New Orleans, LA., Natl. Cotton Council. Am., Memphis, TN. pp. 90-96. 10-14 January 1993.

[16] K.M.K. Doaa, Technological studies some cotton wastes, M.S. Thesis, Fac, Agric., Saba Basha, Alexandria Univ., Egypt. 2003.

[17] W.M.A. Asal, "Effect of cotton fiber properties on yarn quality", M.S. Thesis, Fac, Agric., Saba Basha, Alexandria Univ., Egypt. 2003.

[18] S.H. Sanad, H.E.M. Mahmoud, and M.A.M. El-Sayed, "Production of carded compact cotton yarn of comparable quality to the combed 
conventional ring yarn,” Egypt J Agric Res, Vol. 89, no.1, pp. 203-212, 2011.

[19] M.E. Ureyen and H. Kadoglu, "Regressional estimation of ring cotton yarn properties from HVI fiber properties,"'Textile Res. J., Vol. 76, no. 5, pp. 360-366, 2006.

[20] M.A. Hagar, and A.A. Hassan, "Use of correlation and regression analysis in estimating relative importance of fiber properties affecting yarn hairiness in some Egyptian cotton genotypes," International Journal of Advanced Research, Vol. 4, no. 8, pp. 1274-1284. 2016.

[21] F.S.A. Tolba, Production of low priced, medium and coarse yarns using rotor spinning system, M.S. Thesis. Dep. Agronomy. Fac of Agric. Benha Univ., Egypt. 2017.

[22] A.F.A. Entsar, G.Y.M. Hammam, A.A.A. El- Hosary, E.M.M. ElGedwy, and A.A. Hassan, "Influence of some commercial blends between the imported cotton and the upper Egyptian varieties on technological properties," Annals of Agricultural Science, Moshtohor, Vol. 57, no. 1 pp. 31-38, 2019.

[23] A.E.M. Gadalla and R.M. Abdel-Tawab, "Effect of blending treatments between upland cotton (Gossypium hirsutum L.) and Giza95 cultivar (Gossypium barbadense L.) on fiber and yarn quality," Bulletin of Fac. Agric., Cairo Univ., Vol. 70, no 4, pp. 351-361, 2019.

[24] M.A.M. El-Sayed, and S. H. Sanad, "The impact of new spinning technologies on the Egyptian cottons," Autex Resarch Journal, Vol. 8, no. 4, pp. 231-238, 2007.

Eman Rashwan was born on $5^{\text {th }}$ October 1976 in Egypt. She has master (2009) in Agronomy from Faculty of Agriculture in Cairo University and Ph. D. (2016) in Crop Breeding from Faculty of Agriculture in Ain Shams University. She is a researcher in Spinning Research Department. Cotton Research Institute at Agricultural Research Center (ARC), Egypt. 